\title{
\begin{tabular}{l|l|l} 
Jurnal Kependidikan Dasar & $\begin{array}{l}\text { volume : } 4 \\
\text { Nomor }\end{array}$ \\
Tahun $: 1$ \\
Islam Berbasis Sains
\end{tabular}
}

\section{Pendidikan Khusus Peserta Didik Tunagrahita di SDN Inklusi 4 Karang Patihan Kecamatan Balong Dan SDLB Pertiwi Ponorogo}

\author{
Fuad Fitriawan, Risa Alfiyah Ulfa \\ Institut Agama Islam Sunan Giri Ponorogo \\ fuadfitriawan@gmail.ac.id
}

\begin{abstract}
The purpose of this research to know about Special Service its Implication in education process at SDN 4 Karangpatihan and SDLB Pertiwi Ponorogo. Type of research withcase study through observation, interview and documentation techniques. The analysis through reduction, display and verification data, tested its validity through triangulation. The result is design of special education service for SDN 4 Karangpatihan from cognitive aspect by using the source class as center education for $A B K$, while as affective and psychomotor support is holding of extracurricular scout and karawitan. Form of Special Service Design in SDLB Pertiwi is one by one educational service, means through system 1 teacher 1 student, while in enhancing the spirtual aspect through the habituation of dhuha prayer, while the affective and psychomotor aspects through the art of Reog, Batik, Bojay Sports, , and making a flower arrangement. The obstacle is the complexity of students in tunagrahita.
\end{abstract}

Keyword: Service, Special, Tunagrahita.

\begin{abstract}
Abstrak
Tujuan Penelitian ini adalah untuk mengetahui Bentuk Pedidikan Khusus serta strategi pelaksanaan dan hasil pendidikan di SDN 4 Karangpatihan dan SDLB Pertiwi Ponorogo. Hasil Dari Penelitian ini yaitu bentuk desain layanan pendidikan khusus di SDN 4 Karangpatihan dari aspek kognitifnya adalah dengan penggunaan kelas sumber sebagai center education bagi siswa $A B K$, sedangkan sebagai penunjang afektif dan psikomotornya adalah diselenggarakannya ekstrakurikuler pramuka dan karawitan. Bentuk program pendidikan inklusif di SDN 4 Karangpatihan adalah program pembelajaran intensif di ruang sumber bagi peserta didik tunagrahita yang dilakukan secara kontinyu dengan memperhatikan kebutuhan individualanakuntukmeningkatkan kemampuan dan potensi mereka.Sedangkan di SDLB C Pertiwi Ponorogo bentuk pelayanan pendidikan nya menggunakan pembelajaran intensif 4 hari dan dua 2 dengan kegiatan latih bina diri. Strategi dalam menerapkan program pendidikan inklusif di SDN 4 Karangpatihan yaitu (a) memberikan pembelajaran yang berorientasi pada kebutuhan peserta didik dan kondisi sekolah, (b) pembelajaran ABK secara terpadu (semua ABK belajar dalam satu kelas dengan suasana pembelajaran yang sama) dan (c) peningkatan kualitas guru. Sedangkan di SDLB Pertiwi Ponorogo dengan mengadakan Gebyar ABK dan strategi pembelajaran person by person. Hasil pelaksanaan program pendidikan inklusif di SDN 4 Karangpatihan yaitu dapat memberikan perubahan
\end{abstract}


positif dan bervariatif sesuai potensi dan kebutuhan anak dengan menekankan pada perkembangan kognitif, sedangkan peningkatan aspek sikap dan pikomotorik belum bisa maksimal. Sedangkan hasil pelaksanaan program di SDLB C pertiwi Ponorogo yaitu mereka mampu membaca walaupun belum memahami arti bacaannya, sedangkan dari aspek latih bina diri mampu menghasilkan kemampuan bina diri dan ketrampilan yang baik.

Kata Kunci : $\quad$ Pendidikan Khusus, Tunagrahita.

\section{A. Pendahuluan}

Adanya keragaman budaya masyarakat Indonesia, kondisi lingkungan Ekologis dan Geologis telah menjadi faktor keragaman pendidikan di Indonesia. Adanya keragaman tersebut memunculkan karakter alami dan bawaan perserta didik yang mewarnai pendidikan di Indonesia. Dalam UUD 1945 pasal 31 mengatakan bahwa "setiap warga negara berhak mendapat pengajaran", yang dimaksudkan setiap warga negara adalah manusia yang telah dinyatakan cakap, mampu berkomunikasi, masa kanak-kanak, muda, remaja, hingga Manula baik yang memiliki kondii tubuh seperti pada umumnya maupun mereka yang mengalami disabilitas atau berkebutuhan khusus. ${ }^{1}$ Bagaimanapun mereka adalah manusia yang berhak atas pendidikan dan pengajaran yang sama dengan yang normal. Mereka tetap membutuhkan bimbingan dan dukungan lebih dari sekedar orang tua dan lingkungannya untuk tumbuh dan berkembang sehingga pendidikan yang layak bisa menjadi bagian dari perjalanan hidup mereka.

Dalam proses belajar, peserta didik merupakan salah satu komponen

\footnotetext{
1 Atang Setiawan, Bimbingan Anak Berkebutuhan Khusus (Bandung: UPI Press, 2006), 71.
}

manusiawi yang terpenting. Sebagai salah satu komponen penting dalam sistem pendidikan, peserta didik sering disebut sebagai raw material, ibarat kertas putih yang belum tercoret tinta. Peserta didik dipandang sebagai manusia yang memiliki potensi yang bersifat laten, sehingga dibutuhkan pembinaan dan bimbingan dari guru untuk mengaktualisasikannya agar ia dapat menjadi manusia susila yang cakap. ${ }^{2}$ Sebagai individu yang tengah berkembang, peserta didik memerlukan bimbingan dan pengarahan yang konsisten menuju ke arah titik optimal kemampuannya.

Sejak tahun 1977 masalah anak berkebutuhan khusus atau disabilitas telah ada dan dimulai pengkajiannya dengan kasus anak penderita autis. Menurut WHO Disabilitas adalah sebuah definisi yang memayungi pelemahan, keterbatasan aktivitas, dan halangan dalam berpartisipasi. Pelemahan berarti adanya masalah yang terjadi pada struktur atau fungsi tubuh, keterbatasan aktivitas berarti sebuah kesulitan yang dialami seseorang dalam melakukan tugas atau aksi, sedangkan halangan berpartisipasi berarti sebuah masalah yang dihadapi oleh seseorang dalam menjalani hidupnya. Maka pada dasarnya, penyandang disabilitas membutuhkan intervensi agar bisa menjalankan hidup yang normal dan layak serta menjalankan fungsinya sebagai anggota masyarakat. Namun di sisi lain mereka juga ingin diperlakukan sebagai individu yang setara dan mandiri, tanpa harus mengundang belas kasihan yang berlebihan.

The Salamanca Statement pada tahun 1994 (UNESCO) tentang pendidikan inklusi, menyatakan bahwa setiap anak

\footnotetext{
2 Desmita, Psikologi Perkembangan Peserta Didik (Bandung: Remaja Rosdakarya, 2016), 39.
} 
termasuk yang memerlukan pendidikan khusus sementara maupun permanen mempunyai hak untuk mengikuti proses belajar di sekolah umum. Sekolah umum di sini adalah berbagai lembaga formal (Kelompok Bermain,TK, SD, SMP, SMA, dan SMK) yang menggunakan kurikulum DEPDIKNAS. ${ }^{3}$ Meskipun banyak terjadi perubahan, tampaknya proses belajar mengajar anak di sekolah masih belum berjalan seperti yang diharapkan. Fakta yang diperoleh di lapangan menunjukkan kesenjangan antara apa yang dibutuhkan individu disabilitas dan apa yang disediakan oleh guru, artinya proses pembelajarannya masih belum sesuai dengan kebutuhan siswa disabilitas tersebut.

Salah satu bentuk pendidikan khusus yaitu pendidikan luar biasa. Pendidikan Luar Biasa merupakan pendidikan yang didalamnya memiliki bentuk pendidikan yang menangani kelompok peserta didik yang memiliki keseragaman disabilitas seperti halnya tunarungu wicara. Di Ponorogo saat ini telah ada 3 Sekolah Luar Biasa dengan berbagai jenjangnya, salah satu yang telah lama berdiri adalah Sekolah Luar Biasa (SLB) Pertiwi, berdiri sejak tahun 1977, SLB ini telah melaksanakan pendidikan luar biasa mulai dari TKLB hingga SMALB. Di lembaga tersebut hingga saat ini telah menangani disabilitas siswa berupa siswa autis, tuna rungu wicara dan tuna grahita. Jumlah siswa secara keseluruhan mencapai 150 siswa, kondisi tersebut menurut lembaga telah melebihi kapasitas yang ideal kelas tersebut. Hal tersebut memberikan bukti bahwa jumlah penyandang disabilitas usia pelajar di Ponorogo ternyata cukup banyak.

Berdasarkan uraian tersebut, maka perlu adanya penelitian yang mengkaji tentang desain pendidikan layanan khusus peserta didik tunagrahita dalam kontek pendidikan tingkat sekolah dasar, baik di Sekolah Dasar Inklusif maupun Sekolah Dasar Luar Biasa. Dengan penelitian ini maka dapat mengubah paradigma dalam memahami anak tunagrahita, bahwa individu yang berkebutuhan khusus pun berhak untuk mendapat pegetahuan, membina diri menjadi manusia yang berakhlak mulia, keterampilan dalam hidup sehari-hari dan memanifestasikan perubahan dalam kehidupannya.

\section{B. Metode Penelitian}

Penelitian ini berjenis penelitian studi kasus dengan pendekatan kulaitatif. Creswell ${ }^{4}$ memaparkan fokus studi kasus adalah spesifikasi kasus dalam suatu kejadian baik itu yang mencakup individu, kelompok budaya ataupun suatu potret kehidupan. Adapun untuk pengambilan data mengunakan teknik wawancara, observasi dan dokumentasi, adapun untuk uji keabsahan data menggunakan teknik triangulasi.

\section{Bentuk Pendidikan Layanan Khusus Tunagrahita Di SDN Inklusif 4 Karangpatihan Kecamatan Balong Dan SDLB Pertiwi Ponorogo}

SDN 4 Karangpatihan merupakan salah satu lembaga sekolah yang mulai menyelenggarakan pendidikan inklusif sejak tahun 2010. Di sekolah ini juga telah merancang bentuk program khusus untuk melayani pendidikan bagi anak tunagrahita. Berdasarkan hasil wawancara dengan Kepala Sekolah SDN 4 Karangpatihan yaitu Bapak Mawaludi mengenai bentuk program pendidikan inklusif bagi peserta

4 John W. Creswell, Qualitative Inquiry and Research Design: Choosing among Five Approaches (London: Sage Publications, 1998), 37-38. 
didik tunagrahita di SDN 4 Karangpatihan, beliau mengemukakan bahwa:

Bapak Priyono merupakan salah satu guru senior di SDN 4 Karangpatihan yang lebih mengetahui perkembangan pembelajaran di sekolah tersebut. Beliau menambahkan keterangan tentang bentuk program khusus bagi peserta didik tunagrahita. Adapun hasil wawancaranya sebagai berikut:

SDN 4 Karangpatihan saat ini telah memiliki Tenaga Ahli dibidang Ketunaan sebanyak 2 orang guru yang telah mendapatkan pelatihan khusus Ketunagrahitaan yaitu Bapak Supriono, S.Pd dan Bapak Bayu, S.Pd. Beliau berdua yang menjadi Tenaga Khusus yang ditugaskan untuk menagani sebanyak 21 Siswa ABK dengan berbagai tingkatan ketunaannya yang tersebar di seluruh kelas mulai kelas I sampai kelas IV. Adapun perinciananak ABK dimasing-masing kelas di SDN 4 Karangpatihan adalah sebagai berikut, Kelas I sebanyak 2 siswa, kelas II sebanyak 2 siswa, kelas III sebanyak 3 siswa, kelas IV sebanyak 3 siswa, kelas V sebanyak 5 siswa dan kelas VI sebanyak 9 siswa. ${ }^{5}$

Sebagian besar ABK di SDN 4 Karangpatihan masuk kedalam kategori siswa Slow Learner (Lamban Belajar), sedangkan siswa ABK dengan kategori Tunagrahta sebanyak 2 siswa yaitu siswa yang belajar di kelas 5 bernama Evi Haryuni dan siswa kelas VI dengan nama Dendi Eka Pratama. Adapun Evi Haryuni masuk kedapal kategori C1 yaitu tunagrahita sedang dan Dendi Eka Pratama masuk kategori $\mathrm{C}$ yaitu tunagrahita ringan. ${ }^{6}$

Kurikulum yang digunakan di SDN 4 Karangpatihan adalah Kurikulum KTSP,

\footnotetext{
5 Masnu'ah, Wawancara, Kamis Mei Pukul 08.30 WIB 2018.

6 Masnu'ah, Wawancara, Kamis Mei Pukul 08.30 WIB 2018.
}

sedangkan untuk menangani siswa $\mathrm{ABK}$ di SDN 4 karangpatihan tetap menggunakan kurikulum yang sama namun dalam aplikasinya mulai dari perncanaan, pembelajaran hingga evaluasi disesuaikan dengan kondisi masing-masing siswa ABK. Termasuk ketiak siswa menjelang ujian akhir nasional (UN), siswa tersebut akan dibantu oleh guru kelasnya dalam proses pengerjaan soal-soal UN, dan hal tersebut secara khusus telah menjadi kesepakatan antara pengawas dengan pihak sekolah. Dan ketika mereka lulus saatnya nanti pihak sekolah akan memberikan beberapa rekomendasi khusus mengenai perkembangan anaknya dan rekomendasi mengenai sekolah lanjutan yang cocok bagi anak tersebut.

Adapun bentuk-bentuk program layanan khusus yang ada di SDN 4 Karangpatihan saat ini masih ditekankan pada aspek kognitifnya, adapun aspek afektif dan psikomotorik untuk sementara masih disetarakan dengan siswa yang normal dikarenakan jumlah SDM yang menangani siswa ABK masih kurang. Bentuk layanan khusus pada siswa ABK dari sisi kognitifnya antara lain dengan memanfaatkan sebuah sarana yang disebut dengan kelassumber, kelasini dibuatkhusus bagi siswa $\mathrm{ABK}$, kelas sumber menurut hasil wawancara bersama Bapak Supriyono dijadikan sebagai sarana untuk monitoring perkembangan kognitif siswa $\mathrm{ABK}$, dikelas sumber tersebut sebagaimana pada kelas yang lain juga digunakan sebagai sarana pembelajaran, namun perbedaannya kelas tersebut didalamnya terdapat beberapa alat peraga dasar, diantaranya ada alat peraga angka 1-10 yang disertai gambar, anggota badan yang disertai huruf dan buku bergambar. Kelas sumber digunakan untuk siswa ABK dalam satu minggu sekali 
yang dilaksanakan diluar jam pelajaran sekolah.

Kelas sumber di SDN 4 Karangpatihan masih sangat sederhana hal tersebut dibuktikan dengan adanya kelas yang masih terintegrasi dengan perpustakaan sekolah, inisiatif tersebut sekaligus dalam rangka untuk memfungsikan perpustakaan sebagai sarana literasi dan pembelajaran. Beberapa bentuk kegiatan yang dilaksanakan didalam kelas tersebut seperti hasil observasi peneliti yaitu pengulangan pelajaran yang penekanannya dalam hal baca, tulis dan berhitung, dalam pembelajaran tersebut terpantau beberapa siswa ABK khususnya yang masuk dalam kategori lamban belajar sudah mulai mampu menguasai belajarminimal 2 kata serta berhitung hinga penjumlahan 30 lebih, namun dalam hal menulis masih perlu diintensifkan karena dalam hal tersebut belum bisa tercapai sesuai yang diharapkan. Berikut gambaran prose belajar mengajar di kelas sumber SDN 4 Karangpatihan Ponorogo:

Adapun dari sisi afektifnya secara keseluruhan masih butuh bimbingan langsung dari guru mulai dari sikap, bertata pakaian, berperilaku hingga bertutur kata. Sebagai Pembimbing nya adalah guru agama dan guru kelas. Adapun siswa yang normal dikatakan lebih mudah dalam menerima ajakan baik, perintah dan larangan, adapun siswa ABK cenderung lebih sulit sehingga sosok guru sebagai figur dalam hal tersebut sangatlah dibutuhkan.

Kesulitan tersebut kadang muncul akibat bentuk laku yang hiperaktif yang ditunjukkan oleh siswa $\mathrm{ABK}$, dan rata-rata mereka dari keluarga miskin sehingga pendekatan-pendekatan personal yang dilakukan guru dalam rangka mengatasi perilaku tersebut sering dilakukan, dan hal itu bukan hanya guru BK saja yang melakukan, tapi guru kelas, guru Agama juga melakukan hal yang sama.

Sedangkan bentuk pelayanan khusus bagi ABK di SDN 4 Karangpatihan dari aspek Psikomotorik adalah melalui kegiatan ekstrakurikuler seperti Pramuka, Karawitan dan Reog, namun menurut wawancara yang dilakukan dengan Bapak Imam Arifudin, S.Pd selaku guru karawitan sekaligus sebagai guru yang membidangi olahraga, bahwa pelaksanaan kegiatan ekstra di lembaga tersebut yang berjalan dengan kontinyu hanyalah pramuka dan karawitan, untuk kegiatan pramuka semua ssiwa bisa mengikuti dengan baik, latihan pramuka dilakukan setihap hari sabtu sore yang dipandu oleh seorang Pembina yang diambilkan dari luar sekolah, sedangkan kegiatan karawitan lebih banyak didominasi oleh siswa yang tidak menyandang $A B K$, sedangkan banyak siswa ABK tidak ikut serta didalamnya, menurut pemaparan Bapak Imam bahwa anak ABK sulit untuk diajak untuk kegiatan karawitan, kesulitan tersebut terutama dalam hal mengingat notasi pada alat karawitan yang diajarkan.

Berbeda halnya dengan SDLB Pertiwi Ponorogo, di lembaga tersebut saat ini telah memiliki 12 Guru yang menangani siswa ABK Tunagrahita mulai dari TKLB hingga SMALB, hal tersebut menurut IZahrotul Walidah, S.Pd selaku Kurikulum di SDLB tersbut masih dirasa sangat kurang, karena jumlah siswa seluruhnya sejumlah 72 siswa dan khsusnya siswa SDLB C Pertiwi sebanyak 45 siswa dan ideal kelas adalah adanya 1 guru kelas dan 6 siswa. Namun adanya kekurangan tersebut tidak menyurutkan tenaga pendidik di SDLB tersebut dalam melakukan pelayananpelayanan bagi siswa ABK Tunagrahita.

Adapun bentuk Desain pelayanan Pendidikan khusus yang diberikan di SDLB 
Pertiwi Ponorogo dilakukan dengan melalui tiga aspek pendidikan, yaitu aspek kognitif, afektif dan aspek psikomotorik. Adapun dari aspek kognitif bentuk pelayanannya adalah pelayanan yang langsung di handle oleh wali kelas sekaligus sebagai guru kelas dan BP, desain yang diterapkan dalam aspek tersebut disesuaikan dengan standar pendidikan khusus yaitu satu kelas hannya diisi oleh maksimal 8siswa ABKtunagrahita. Adapun bentuk kurikulum yang ada di lembaga tersebut sama dengan kurikulum yang ada di SD pada umunya dimana saat ini SDLB C Tunagrahita telah menggunakan Kurikulum 2013, namun di SDLB materi pembelajarannya disederhanakan dan disesuaikan dengan kondisi siswa tersebut.

Untuk pembelajaran siswa secara dominan pada aspek kognitifnya dilakukan dengan mengenalkan huruf abjad melalui baca tulis secara intensif, pengenalan huruf tidak dimulai dari huruf vokal $(\mathrm{a}, \mathrm{i}, \mathrm{u}, \mathrm{e}, \mathrm{o})$, namun dimulai dengan huruf konsonan yang kemudian dihubungkan dengan huruf vokal, adapun kompetensinya siswa dapat membaca susunan huruf dalam kata yang dituliskan oleh guru. Demikian seterusnya hingga beberapa siswa di kelas VI sudah mampu membaca walaupun masih sulit untuk memahami bacaan yang dibacanya.

Porsi yang diberikan dalam proses belajar mengajar di SDLB pertiwi Ponorogo dilaksanakan dalam 4 hari, yaitu hari senin hingga kamis, sedangkan hari jum'at dan hari jumat digunakan untuk kegiatan bina diri dalam kegiatan kepramukaan dan hari sabtu digunakan untuk pembelajaran minat dan bakat siswa dan bina diri. Menurut pemaparan IZahrotul Walidah, S.Pd bahwa pembelajaran khusus bagi anak tunagrahita memang demikian adanya, pembelajaran yang sifatnya kognitif hanya dilakukan dalam waktu 4 hari, hal demikian dilakukan karena keadaan siswa yang lemah dalam aspek kognitifnya, mereka memiliki keterbatasan dalam proses belajar baca tulis dan berhitung, namun pada aspek lain seperti menggunakan HP Android, latih tarik suara dan kerajinan mereka tidak kalah dengan anak yang normal pada umumnya. Sehingga kegiatan yang sifatnya digunakan untuk penyeimbang maka dilakukan dengan cara mengembangkan sikap afektif dan psikomotoriknya di hari jumat dan sabtu.

Sedangkan bentuk layanan khusus dari aspek afektif yang dilakukan lembaga tersebut berdasarkan hasil wawancara dengan IZahrotul Walidah, S.Pd adalah dengan melakukan program Bina Diri, yaitu sebuah program pelayanan khusus dalam mengembangkan potensi peserta didik melalui pembiasaan berperilaku sehari-hari untuk menolong dan mengurus dirinya sendiri. Pembiasaan diri ini secara langsung dilakukan di Sekolah mulai dengan mengajarkan cara mandi sendiri, menggosok gigi, menyapu halaman hingga memasak. Dengan Bina Diri diharapkan siswa dengan mandiri bisa melakukan perkejaan yang ada hubungannya dengan dirinya secara mandiri.

Selain itu juga dilakukan pembinaan spiritual yaitu pembinaan dengan mengajari mereka Sholat lima waktu, berperilaku sopan santun kepada orangtua dan kepada guru, juga dilaksanakan beberapa kegiatan yang ada hubungannya dengan PHBI seperti kegiatan Pondok Romadhon. Kegiatan pondok romadhon dilakukan dengan sistem full day pagi hingga sore hari di sekolah dalam 3 hari, pada kegiatan tersebut lebih ditekankan kegiatannya pada askpek spiritual secara intensif melalui ceramah maupun 
pembiasaan sholat fardhu berjamaah, baca tulis al-Qur'an.

Adapun dalam aspek Psikomotorik siswa lebih banyak dilatih dalam beberapa ketrampilan prakarya sebagai bentuk latihan softskill dan olahraga sebagai bentuk pelatihan hardskill, adapun ketampilan prakarya yang dilaksanakan adalah ketrampilan meronce, melipat, menggambar, membatik, menjahit, menyablon. Sedangkan dalam bidang olahraga bentuk pengembangannya dengan melakukan pelatihan bola bojay dan lari. Namun seiring dengan berjalannya waktu, kegiatan ekstra yang masih berjalan sebagai penunjang psikomotorik siswa adalah kepramukaan, membatik dan bola bojay, sedangkan kegiatan yang lain tidak dapat dilaksanakan karena sumber daya manusia siswa yang tidak mendukung.

Gambar diatas merupakan kegiatan latihan bola bojay yang disiapkan untuk kegiatan lomba paralimpic di Jawa Timur. Bola bojay merupakan cabang olahraga bagi penyandang cacat Tunagrahita dimana bola dipegang oleh pemain kemudian diarahkan dengan cara dilempar ke titik bola kecil didepannya, semakin bola tersebut dekat dengan bola kecil maka score yang diperoleh akan semakin banyak.

Pendidikan inklusif merupakan sekolah yang memiliki prinsip dasar pendidikan untuk semua (education for all) yaitu semua anak dalam batasa usia pelajar bisa belajar di lingkungan yang sama baik anak dengan kondisi normal maupun anak yang berkebutuhan khusus (ABK) tanpa memandang bentuk-bentuk kelainannya, tanpa adanya diskriminatif dari lingkungan belajar dan saling menghargai keanekaragaman yang bertujuan untuk mewujudkan kesempatan yang seluasluasnya kepada peserta didik berkebutuhan khusus memperoleh pendidikan yang bermutu untuk mengembangkan bakat dan minatnya sesuai dengan kebutuhan dan kondisinya, sehingga perlu adanya penyesuaian baik pendidik, tenaga kependidikan, sarana dan prasarana, kurikulum dan sistem penilaiannya berdasarkan dengan kebutuhan peserta didik.

Peserta didik tunagrahita merupakan peserta didik yang dikategorikan mengalami kelemahan mental dan memiliki IQ <70 di bawah rata-rata anak normal dengan disertai ketidakmampuan dalam penyesuaian perilaku dan terjadi pada masa pertumbuhan. Peserta didik tunagrahita daapt digolongkan menjadi 2 yaitu peserta didik tunagrahita ringan (C) dan peserta didik tunagrahita berat (C1). Adapun peserta didik dengan kategori $\mathrm{C}$ masih memiliki kemampuan untuk bina, latih dan calistung, sedangkan peserta didik yang mengalami keterbelakangan mental kategori C1 sangat sulit bahkan tidak dapat belajar secara akademik seperti membaca, menulis dan berhitung, hanya latih bina yang dapat diajarkan pada anak ini.

Anak dengan kategori C1 atau Embisile sebenarnya sejak usia dini mereka telah diketahui ciri fisiknya, yaitu memiliki cirri wajah mongoloid, yaitu telinga kecil, hidung bulat kelopak mata cenderung merapat, lidah pendek, jari jari pendek. Maka jika hal tersebut terlihat pada seorang anak, maka sudah bias diketahui bahwa anak tersebut kemungkinan besar mengalami kelainan yaitu embisile.

Dalam rangka mewujudkan pendidikan inklusif di SDN 4 Karangpatihan, yaitu pendidikan yang terbuka dan ramah untuk menerima perbedaan anak sesuai kondisinya, maka perlu dirancang programprogram dalam melayani dan membimbing 
pesertadidikkhususnya anakberkebutuhan khusus. Program yang dirancang khsusu tersebut salah satunya yaitu pembelajaran intensif di ruang sumber bagi peserta didik berkebutuhan khusus. Disebut sebagai ruang sumber karena diruangan tersebut perserta didik tunagrahita dan peserta didik lamban belajar diharapkan mampu belajar baik, sehingga ketika keluar dari ruang tersebut, anak $\mathrm{ABK}$ mendapati dirinya telah berkembang.

Dari hasil wawancara di SDN 4 Karangpatihan Balong Ponorogo, ruang sumber merupakan sebuah ruang yang digunakan sebagai pusat pelayanan pendidikan bagi peserta didik berkebutuhan khusus. Program ini merupakan program yang diselenggarakan setelah SDN 4 Karangpatihan ditunjuk menjadi sekolah inklusif oleh Dinas Pendidikan Ponorogo pada tahun 2010. Pelaksanaan program pembelajaran di ruang sumber dibuat oleh pihak sekolah dengan memperhatikan kondisi lingkungan sekolah tersebut. Selain itu, ide program ini dapat terealisasi karena adanya sebuah pelatihan dan workshop mengenai pelayanan khusus anak berkebutuhan khusus di sekolah inklusif yang diikuti oleh guru-guru di SDN 4 Karangpatihan.

Pelayanan pembelajaran di ruang sumber dilaksanakan secara kontinu setiap seminggu sekali yaitu pada hari Sabtu, namun dapat diadakan pergantian hari jika terjadi halangan. Pembelajaran dilakukan selama dua kali jam pelajaran atau sekitar 2 x 40 menit dengan didampingi oleh dua orang guru yang bertanggungjawab di ruang sumber tersebut. Karena sulitnya mencari tenaga pendidik dan kependidikan yang berlatarbelakang Pendidikan Luar Biasa, maka pembelajaran masih didampingi oleh guru-guru dari sekolah tersebut, namun mereka telah diberikan pelatihan-pelatihan dan workshop.

Proses pembelajaran di ruang sumber tersebut tidak jauh berbeda dengan kegiatan pembelajaran di kelas anak normal pada umumnya. Hanya saja materi yang disampaikan lebih sederhana menyesuaikan kemampuan dan kebutuhan peserta didik. Materi yang diberikan yaitu tentang pembelajaran membaca, menulis dan berhitung secara sederhana. Selain itu diberikan pembelajaran bina diri seperti pembiasaan perilaku dalam sehari-hari dan pembuatan keterampilan sederhana, seperti membuat hasta karya, menggambar, melipat, dll. Walaupun anak tunagrahita mempunyai kelemahan dalam aspek kognitif dan intelektual, namun mereka sisws ABK di SDN 4 Karangpatihan masih bisa diberikan penanaman sikap yang baik dan keterampilan-keterampilan.

Dari bentuk program yang dilaksanakan di SDN 4 Karangpatihan Balong Ponorogo dapat diketahui bahwa pendidikan inklusif merujuk pada pendidikan untuk semua yang berusaha menjangkau semua anak tanpa kecuali. Dengan demikian berarti semua anak belajar dalam satu sistem pendidikan yang sama tetapi dengan layanan yang berbeda-beda sesuai kebutuhan-kebutuhan belajar peserta didik. Oleh sebab itu, misi pendidikan yang paling penting adalah meminimalkan hambatan belajar dan memenuhi kebutuhan belajar anak. Sehingga setiap anak akan berkembang optimal sejalan dengan potensi masing-masing.

Jadi, bentuk program pendidikan inklusif yang dilaksanakan di SDN 4 Karangpatihan adalah pembelajaran intensif di ruang sumber bagi peserta didik tunagrahita dengan tujuan memberikan kesempatan belajar untuk semua peserta 
didik khususnya tunagrahita yang mana penerapan pembelajarannya dilakukan di lingkungan sekolah yang sama namun bentuk layanannya berbeda-beda sesuai kebutuhan dan potensi masing-masing anak.

Kedepan perlu adanya pengembangan kelas sumber tersebut, menurut hemat penulis adanya model-model pembelajaran yang representative pada dasarnya juga sangat diperlukan untuk diaplikasikan dalam kelas sumber tersebut. Di SDN 4 Karangpatihan berdasarkan pengamatan penulis masih sangat minim akan adanya kelas berbasis tenkologi informasi, seyogyanya sebagai sekolah dasar negeri adanya teknologi informasi menjadi hal yang terjangkau sebagai pelengkap proses belajar mengajar di SDN tersebut. Selain hal itu perlunya ruang yang indemenden dan representatif untuk kelas sumber sebenarnya juga sangat diperlukan. Jika kelas tersebut secara independen ada maka keberadaannya bisa sangat representative dan sangat berpotensi untuk dikembangkan.

Berbeda halnya dengan program layanan pendidikankhususyangada diSDLB C Pertiwi Ponorogo. Adanya homogenitas siswa di SDLB tersebut memudahkan guru dalam menyiapkan bahan belajar dan pembelajarannya. Sekaligus adanya program pelayanan pembelajaran yang mengarak keranah pembelajaran kognitif, afektif dan psikomotorik bisa dilakukan dengan terpadu dalam layanan pendidikan tersebut.

Adanya pembelajaran yang sangat mendasar pada ranah kognitif yaitu dengan mengenalkan huruf konsonan dan huruf vocal yang dilakukan dalam satu semester dan dilanjutkan pada semester berikutnya merupakan suatu hal yang wajar yang ada di SDLB C Pertiwi Ponorogo. Memang hal tersebut dilakukan dikarenakan kondisi siswa yang memang benar-benar belum mengenal huruf dan angka. Disamping itu adanya kegiatan penunjang ekstrakurikuler dilakukan sebearnya dalam rangka untuk menyeimbangkan kemampuan kognitif dan kemampuan lainnya, karena jika terus menerus proses belajar mengajar dilakukan di dalam kelas dengan mengenalkan huruf dan angka mereka akan cepat jenuh.

Secara kualitas adanya keseragaman siswa yang demikian sebenarnya dapat memudahkan guru dalam mengelola kelas, namun keadaan tersebut juga yang menuntut guru untuk terus intens dalam membina siswa, karena disamping keadaan yang sama adanya perhatian yang khusus juga menjadi aspek penting dalam mengelola kelas, karena bisa jadi jika ada keteledoran dalam pengelolaan kelas akan berdampak kurang baik bagi kelas dan siswa tersebut.

\section{Strategi Layanan Pendidikan Khusus Tunagrahita}

Adapun bentuk strategi agar pelaksanaan program pendidikan layanan khusus di SDN 4 Karangpatihan bisa berjalan dengan baik khsusnya dalam melayani siswa $\mathrm{ABK}$, maka ada beberapa strategi yang telah dilakukan oleh lembaga tersebut. Menurut pemaparan Bapak Mawaludi, S.Pd bahwa sebagai strategi pelaksanaanya dilakukan pembinaan khusus bagi guru yang mengampu pembelajaran khusus bagi siswa ABK. Diantaranya adalah dengan mengirimkan Bapak Supriyono dan bapak Bayu, S.Pd guna untuk mengikuti Training di Malang, pembinaan Rutin Guru ABK oleh sekolah pendamping. Adapun keikutsertaan training tersebut telah dilakukan pada 
tahun 2010. Dan setelah itu belum ada training lagi kecuali dilakukannya pembinaan-pembinaan oleh sekolah pembina. Adapun pembinaan oleh sekolah pembina dilakukan dengan menggunakan momen pertemuan workshop, seminar, lokakarya yang dilakukan oleh dinas pendidikan Kab. Ponorogo. Serta melalui pemberian modul-modul yang dapat menjadi referensi pustaka bagi guru ABK.

Selain itu bentuk optimalisasi adanya kelas sumber juga menjadi salah satu bentuk strategi pelaksanaan program layanan khusus bagi siswa tunagrahita, karena pada awal ketika menyandang status inklusif, SDN 4 Karangpatihan telah banyank menerima siswa $\mathrm{ABK}$, namun ketersediaan kelas sumber saat itu belum ada, baru tahun 2016 kelas tersebut ada.

Kemudian bentuk strategi lain agar layanan bagi ABK di SDN 4 Karangpatihan bisa berjalan dengan baik, maka bentuk kelas terpadu antara ABK dan siswa yang normal juga perlu dilakukan, walaupun mereka berbeda dalam beberapa hal namun kelas terpadu bertujuan supaya dalam aspek sosial siswa tetap belajar untuk berinteraksi dengan teman sebaya nya.

Sedangkan bentuk strategi yang dilakukan oleh SDLB pertiwi Ponorogo agar pelaksanaan pendidikan khusus bisa berjalan dengan baik adalah dengan melakukan sosialisasi dan peningkatan SDM. Karena Lembaga tersebut secara administratif dan tanggungjawabnya langsung ke kantor wilayah jawa Timur, maka banyak pelatihan yang sifatnya untuk meningkatkan Kapasitas SDM Guru yang secara periodik telah dijadwalkan oleh Kantor Wilayah Jawa Timur. Selain itu pemilihan calon guru baru juga diselesksi sesuai dengan kapsitas akademiknya, pemilihan antara guru dengan latar belakang pendidikan Luar Biasa dengan latar belakang pendidikan ketunaan khusus misalanya pendidikan tunagrahita menjadi prioritas pendidik di Lembaga tersebut. Sehingga spesifikasi pendidikan menjadi sangat penting bagi kelangsungan proses belajar mengajar di SDLB C peritiwi Ponorogo.

Kemudian Strategi desain layanan pendidikan khusus lainnya adalah dengan melalui kegiatan sosialisasi biasanya dilakukan dengan membuat konsep acara bernama Gebyar ABK. Acara ini dilaksanakan dengan tujuan untuk mengenalkan lembaga tersebut kepada masyarakat serta memberikan keyakinan kepada masyarakat bahwa ABK pada adasarnya bisa dididik melalui pendidikan formal sebagaimana anak pada umumnya, dengan adanya acara tersebut diharapkan banyak orang tua yang menjadi lebih sadar akan pendidikan anaknya meskipun anak tersebut menyandang disabilitas. Karena menurut Ibu masnu'ah, S.Pd bahwa pendidikan anak berkebutuhan khsuus adalah pendidikan yang berbeda dari pada umumnya, semakin dini orang tua tanggap akan keadaan anaknya itu dan kemudian memiliki inisiatif untuk dimasukkan dalam lingkungan pendidikan khusus, maka anak akan semain mengetahu jatidirinya dan anak akan cepat belajar untuk menjadi lebih baik. Hal tersebut sesuai dengan hasil wawancara dengan beliau:

"Anak yang memiliki kekhusususan seperti tunagrahita bahkan juga tunarunguwicara itu jika segera disekolahkan mereka akan segera tau dan mengerti dirinya, karena hanya sekolah yang bias menangani mereka, karena jika terlalu lama dirumah mereka akan sulit untuk diajari bina diri dan lainnya". ${ }^{7}$

7 Wawancara, Kamis Mei Pukul 08.30 WIB 2018. 
Kemudian dalam proses belajar Juga membantu guru agar memiliki mengajar, siswa dalam belajar dikelas dilayani oleh satu guru sekaligus sebagai guru konselingnya. dalam belajar siswa guru melakukan proses pembelajaran dengan sistem person by person. artinya dalam proses belajar megajar siswa tunagrahita sangat baik jika mereka dilayani satu persatu, hal ini sekaligus untuk meningkatkan ikatan emosional antara guru dan siswa.

Selain itu beberapa strategi desain layanan yang dilakukan oleh lembaga tersebut guna mencapai hasil yang maksimal adalah dengan mencoba melatih kemampuan hard skill disamping soft skill yang ada pada peserta didik. Diantaranya pelatihan dalam membuat anyaman dan tata boga, harapannya adalah jika secara kognitif mereka tergolong lambat dalam menguasaan materi bahkan sulit, maka harapannya dengan pelatihan hard skill siswa secaramotorik mampu melakukan hal-hal yang bisa menjadi modal masa depan mereka. Kemudian untuk menghargai hasil karya mereka, dalam ajang dan moment tertentu hasil mereka dipamerkan pada beberapa acara diantaranya dalam acara gebyar ABK yang agenda acara tersebut ada setiap tahun sekali yang bertempat di aloon aloon Kabupaten ponorogo bersama dengan SLB lain di Ponorogo.

Strategi pembelajaran merupakan serangkaian rencana kegiatan yang termasuk didalamnya penggunaan metode dan pemanfaatan sumber daya atau kekuatan dalam suatu pembelajaran. Perencanaan strategi pembelajaran perlu dilakukan agar mencapai tujuan yang telah direncanakan dan mendapatkan hasil yang maksimal. Manfaat adanya strategi pembelajaran diantaranya adalah peserta didik dapat terlayani kebutuhan belajarnya. gambaran bagaimana cara membantu peseta didik dalam kegiatan belajarnya.

Penyelenggaraan program pendidikan inklusif seharusnya menyesuaikan dengan keadaan dan sumber daya yang ada di lingkungan sekolah tersebut. Oleh karena itu, pihak sekolah perlu membuat perubahan mulai dari cara pandang, strategi-strategi pembelajaran, sampai pada proses pendidikan yang berorientasi pada kebutuhan individual peserta didik dengan memperhatikan kondisi lingkungan sekolah. Dalam rangka mengoptimalkan pembelajaran intensif di ruang sumber, yang mana digunakan sebagai pusat pelayanan pendidikan bagi anak berkebutuhan khusus. Maka perlu adanya langkah-langkah atau strategi dalam melaksanakan program tersebut.

Dari hasil wawancara di SDN 4 Karangpatihan Balong Ponorogo, bahwa strategi yang digunakan dalam mengoptimalkan fungsi ruang sumber sebagai pusat pelayanan pendidikan $A B K$ yaitu pertama, memberikan pembelajaran yang berorientasi pada kebutuhan peserta didik dengan menyesuaikan keadaan lingkungan sekolah. Wujud nyata dari adanya pengakuan dan penghargaan terhadap keragaman anak adalah adanya proses pembelajaran yang fleksibel. Fleksibilitas dapat diwujudkan dalam bentuk penyesuaian kurikulum dengan kebutuhan anak dan pembelajaran tidak lagi berpusat pada kurikulum melainkan berpusat pada anak. Sebagai contoh penggunaan RPP yang dimodifikasi sesuai kebutuhan siswa baik dari strategi pembelajaran maupun materi yang disampaikan.

Selain itu pelaksanaan pembelajaran juga harus memperhatikan keadaan dan 
sumber daya sekolah yang mendukung, baik itu sarana prasarana, guru, maupun kondisi lingkungan sekitar. Oleh karena itu, pembelajaran inklusif di SDN 4 Karangpatihan dilaksanakan dengan tujuan utama mengembangkan potensi peserta didik sesuai kebutuhannya dengan memanfaatkan keadaan lingkungan sekolah.

Kedua, pembelajaran ABK yang dilaksanakan secara terpadu. pembelajaran terpadu yang dimaksudkan adalah pembelajaran dengan mempertemukan dan memadukan semua ABK dalam satu kelas yaitu di ruang sumber melalui kegiatan belajar mengajar secara bersamasama. Berdasarkan hasil wawancara dan dokumentasi, bahwa ABK yang ada di SDN 4 Karangpatihan mayoritas adalah anak lamban belajar dan tunagrahita, sedangkan terdapat sekitar 5 anak tunadaksa dan hiperaktif. Tujuan pembelajaran terpadu adalah berusaha memberikan kesempatan kepada semua anak berkebutuhan khusus untuk saling berinteraksi dan saling membantu dalam kondisi mereka yang sama-sama mempunyai keterbatasan. Dengan suasana pembelajaran yang berbeda dari kelas sebelumnya, maka diharapkan mereka termotivasi untuk belajar dan mengembangkan potensinya.

Strategipembelajaranterpadu dianggap efektif dilaksanakan di sekolah tersebut, karena faktor-faktor sebagai berikut jika dilakukan pemisahan kelas berdasarkan kecacatan peserta didik, maka diperlukan beberapa ruang sumber untuk proses pembelajaran agar lebih maksimal. Hal ini tidak mungkin dilakukan karena kurangnya sarana gedung dan alat-alat pembelajaran yang lain. Faktor lainnya, karena ketiadaan tenaga pendidik dan kependidikan khusus Pendidikan Luar Biasa dan masih terbatasnya guru yang mengikuti pelatihan khusus ABK, sehingga jika dilakukan pemisahan kelas juga membutuhkan guru yang bertanggungjawab di setiap kelasnya.

Ketiga, meningkatkan kualitas guru. Kemampuan guru menjadi salah satu pendukung keberhasilan dalam proses pembelajaran. Khususnya guru di sekolah inklusif yang harus mampu melayani semua peserta didik berdasarkan kebutuhannya. Pada awalnya SDN 4 Karangpatihan merupakan sekolah reguler yang kemudian diselenggarakan pendidikan inklusif, sehingga di sekolah tersebut belum ada guru yang berlatar belakang Pendidikan Luar Biasa. Pelatihan dan workshop pernah diikuti oleh beberapa guru tetapi belum secara berkelanjutan. Oleh karena itu, perlu diadakan peningkatan kualitas guru melalui program-program khusus dari pemerintah, baik pelatihan, workshop maupun sosialisasi dengan pusat sumber Sekolah Luar Biasa dalam rangka pengembangan penyelenggaraan pendidikan inklusif bagi ABK.

Dengan demikian ketiga strategi yang efektifdilaksanakandiSDN4 Karangpatihan adalah (a) memberikan pembelajaran yang berorientasi pada kebutuhan peserta didik dan kondisi sekolah, (b) pembelajaran ABK secara keterpaduan (c) peningkatan kualitas guru. Tujuan dari penerapan strategi ini adalah untuk meningkatkan kemampuan dan potensi peserta didik berkebutuhan khusus demi kelangsungan hidupnya di masa yang akan datang.

Sedangkan bentuk strategi layanan pendidikan khusus di SDLB C Pertiwi Ponorogo telah dilakukan diantaranya dengan bentuk perayaan yang disebut dengan Gebyar ABK, hal tersebut dilakukan untuk menunjukkan eksistensi akan adanya lembaga yang melayani anak berkebutuhan 
khusus. adanya gebyar tersebut digunakan untuk membuktikan bahwa peserta didik tunagrahita dapat dilatih dan diajari, dengan adanya pendidikan yang mewadahi anak tunagrahita, diharapkan anak nantinya mampu mandiri dalam aktivitas sehari-hari hingga mereka mampu secara akademik berdasarkan kemampuan mereka.

Adapun bentuk strategi lain dalam pelayanan pendidikan tunagrahita di SDLB C Pertiwi Ponorogo adalah dengan melakukan pembinana sistem person by person secara intensif. Adanya pembinaan secara intensif akan sangat membantu dalam mencapai kompetensi siswa tumagrahita khususnya dalam aspek kognitif baca tulis dan dan berhitung. Pembinaan yang intensif memang sangat dibutuhkan bagi $\mathrm{ABK}$, mengingat mereka memiliki kelambanan dalam belajar. Bahkan dengan adanya pembinaan intensif pun kadang siswa masih sulit untuk berkembang.

Adanya variasi dalam proses belajar mengajar memang sangat diperlukan. Tuntutan seorang guru dalam varasi mengajar menjadi tantangan tersendiri. Bahkan bagi mereka yang memiliki kebutuhan khusus pun juga berhak mendapatkan pembelajaran yang variatif, sehingga sudah semestinya SDLB C Pertiwi Ponorogo menerapkan hal itu. Dalam hal ini Lembaga tersbeut telah menerapkan sistem pembelajaran yang mengedepankan aspek keseimbangan. Yaitu dengan melakukan proses belajar mengajar di hari Senin hingga kamis, sedangkan hari Jum'at diadakan kegiatan Pramuka dan hari Sabtu digunakan untuk menanamkan proses pembiasaan dan mewadahi minat dan bakat anak Tunagrahita.

Jadi adanya strategi yang diterapkan oleh SDLB C Periwi Ponorogo sebagaimaa tersebut diatas saat ini masih berjalan, dan eksistensi Lembaga tersebut saat ini juga masih bias diandalkan, walaupun beberapa kendala yang muncul yaitu minimnya tenaga pengajar muda dengan kualifikasi pendidikan luarbisa adalah tantangan tersebidir, disamping banyaknya guruguru senior yang telah purna.

\section{Capaian Layanan Pendidikan Khusus Tunagrahita}

Adapun hasil program layanan khusus yang telah terlaksana di SDN 4 karang patihan antara lain yaitu keberadaan Sarana kelas Sumber menjadi salah satu sarana yang sangat representatif bagi siswa lamban belajar dan siswa tunagrahita, dari hasil pengamatan yang dilakukan, program intensifikasi $\mathrm{ABK}$ di kelas sumber yang dilakukan secara terus menerus mampu meningkatkan kemampuan kognitif siswa utamanya dalam materi membaca menulis dan berhitung.

Misalnya dari hasil observasi peneliti yaitu pada kemampuan berhitung dan membaca, beberapa siswa yang sudah kelas 3 dan 4 yang berstatus ABK sudah mampu membaca, menulis dalam 3 hingga lima kata, yang pada mulanya ketika mereka kelas 2, mereka masih sangat lemah dalam membaca dan berhitung. Adapun kemampuan berhitung telah meningkat dari kemampuan berhitung angka 1 hingga 10 menjadi 1 hingga angka 50.Dalam konteks kompetensi dasar siswa kelas yang setara. Pada dasarnya kemampuan tersebut masih sangat jauh bila dibandingkan dengan siswa pada umumnya dengan kelas yang sama, namun karena ini merupakan siswa ABK maka hal tersebut sudah dianggap berkembang dengan baik.Berikut disajikan gambar berupa suasana kegiatan belajar di ruang sumber SDN 4 karangpatihan. 
Keberadaan alat peraga yang terintegrasi dengan kelas sumber diketahui sangat membantu dalam menunjang keberhasilan proses belajar membaca menulis dan berhitung siswa ABK. Keberadaan Guru yang secara khusus menjadi konselor bagi siswa ABK menjadi satu hal yang menetukan keberhasilan mereka, adanya keterikatan emosional anata siswa $\mathrm{ABK}$ dan guru ternyata telah menjadi satu sebab siswa tersebut mampu menguasai pelajaran dengan lebih baik dibanding sebelum dilaksanakan kegiatan di kelas sumber.

Adanya pembinaan guru ABK di lembaga tersebut menjadi pemicu keterampilan guru dalam membina siswa ABK yang secara formal tidak mampu dilaksanakan oleh guru lain dalam satu lembaga tersebut. Sehingga keberadaan guru ABK secara khusus memang menjadi kunci keberhasilan dalam pelayanan siswa lamban belajar dan siswa tunagrahita di SDN 4 karangpatihan.

Adapun hasil dari program layanankhusus di SDLB pertiwi ponorogo antara lain yaitu bahwa siswa tunagrahita dalam aspek kognitif bisa berkembang dengan baik melalui pembelajaran intensif person by person, pada prinsipnya pembimbingan dengan melibatkan 1 wali kelas dengan 5 hingga 6 siswa akan memberikan dampak yang efektif dalam proses membangun aspek kognitif siswa tunagrahita di lembaga tersebut, dari hasil wawancara yang telah dilakukan dengan Zahrotul Walidah, S.Pd diketahui bahwa pembelajaran dengan menggunakan sistem belajar intensif menjadi salah satu strategi yang dapat meningkatkan kemapuan kognitif siswa tunagrahita di lembaga tersebut. Beberapa contoh siswa yang sudah dianggap maju oleh guru adalah siswa kelas 6 yang telah mampu membaca buku bacaan, Waupun dalam membaca mereka tidak mengerti arti dari kata yang dibacanya itu.Berikut kutipan wawncara dengan bu Zahrotul Walidah, S.Pd selaku waka kurikulum di SDLB Pertiwi Ponorogo:

\begin{abstract}
"Đalam membelajarkan siswa tunagrahita guru menggunakan teknik person by person, karena sifat karakter pribadi siswa tunagrahita tidak sama, sehingga dengan metode tersebut siswa akan berkembang. Hasil yang Nampak dari latihan membaca anak kami berupa kemampuan membaca dari seagian kecil anak didik kami, namun belum mengerti arti bacaannya itu." ${ }^{\prime}$
\end{abstract}

\section{Gambar 12. siswa SLB Pertiwi Ponorogo berlatih mengeja dan membaca}

Selain dari hal tersebut diatas, juga dengan melalui pendekatan emosional, misalnya dengan sistem kunjungan kerumah peserta didik dalam rangka memberikan motivasi untuk belajar dan terus bersekolah, memberikan dampak yang sangat baik bagi perkembangan kognitif dan perkembangan afektif siswa tunagrahita. System kunjung rumah ini menjadi salah satu cara dianggap berhasil dalam rangka mengajak siswa Tunagrahita untuk teteap terus belajar. Waktunyapun sangat bervariasi, pagi hingga amalm hari guru siap meluangkan waktunya untuk kunjung kerumah siswa, walaupun hanya sekedar memotivasi untuk mau makan dan mandi.Hal tersebut sudah menjadi kegiatan rutinitas guru ABK dalam rangka membelajarkan siswa tunagrahita.

Kemudian dengan melakukan berbagai pelatihan melalui pembinaan ekstrakurikuler siswa tunagrahita bisa lebih terampil minimal dalam hal urus diri sendiri dan tentunya lebih dari itu siswa

8 Zahrotul Walidah, Wawancara, Kamis Mei Pukul 08.30 WIB 2018, 3. 
mampu melatih potensi non akademiknya untuk diterapkan dalam kehidupan seharihari. Hal tersebut didasarkan pada hasil dokumentasi beberapa hasta karya dan beebrapa kegiatan ekstrakurikuler siswa tunagrahita yang secara umum telah memberikan harapan yang lebih baik bagi masa depan siswa tunagrahita tersebut.

Keberhasilan implementasi pembelajaran dapat diketahui dari adanya perubahan menuju peningkatan kemampuan pada peserta didik baik secara kognitif, afektif, dan psikomotorik. Program pembelajaran dirancang oleh sekolah agar mencapai hasil yang maksimal. Pada kenyataannya banyak terjadi pada peserta didik yang mengalami kondisi sebaliknya, perubahan justru menuju kearah penurunan dan melemahnya kemampuan peserta didik. Hal ini dapat disebabkan karena faktor permasalahan individu peserta didik seperti kurangnya motivasi belajar atau kesulitan dalam belajar, faktor guru yang kurang menguasai dalam menyampaikan materi, faktor sarana dan prasarana yang kurang mendukung, atau karena pengaruh peyalahgunaan teknologi bagi anak. Beberapa faktor tersebut dapat menghambat implementasi pembelajaran di sekolah, sehingga akan berdampak buruk terhadap hasil belajar peserta didik.

Begitu pula dengan pelaksanaan program pelayanan pendidikan yang berpusat di ruang sumber dapat memberikan perubahan yang baik bagi peserta didik tunagrahita di SDN 4 Karangpatihan. Dari hasil wawancara diketahui bahwa dengan adanya ruang sumber dapat berdampak positif dalam meningkatkan kemampuan peserta didik tunagrahita. Perkembangan anak dapat dilihat dari adanya perubahan yang awalnya mereka tidak bisa membaca, menulis dan berhitung, namun melalui ruang sumber tersebut anak mulai bisa calistung dengan materi yang sederhana. Sehingga secara kognitif, peserta didik tunagrahita juga mengalami peningkatan, meskipun tidak bisa maksimal dan signifikan seperti kemampuan anak normal.

Bagi peserta didik normal, hasil belajar dapat dinilai dengan adanya peningkatan pada aspek kognitif, sikap dan keterampilan. Ketiga aspek tersebut menjadi acuan untuk pembuatan evaluasi pembelajaran yang digunakan sebagai tolak ukur keberhahasilan belajar juga didasarkan pada perkembangan aspek kognitif, afektif dan psikomotorik dari peserta didik. Namun dalam pelaksanaan penilaiannya sangat jauh berbeda dengan anak normal. Dari aspek kognitif, peningkatan dan pemahaman materi sulit untuk dilakukan, karena kemampuan IQ nya yang sangat rendah. Namun bagi tunagrahita dengan kategori ringan, mereka masih bisa diberikan pembelajaran bina diri dan keterampilan-keterampilan sederhana dengan tujuan agar dapat menjalani kehidupannya secara mandiri tanpa membebani orang lain.

Pembelajaran bina diri dilakukan melalui pembiasaan ketika proses belajar mengajar berlangsung, misalnya menyapu, mencucitangan sebelum makan, membuang sampah di tempatnya, dll. Sehingga anak dapat menerapkan kebiasaan-kebiasaan tersebut di rumah. Sedangkan keterampilan yang diberikan yaitu sesuai kemampuan peserta didik, seperti membuat hasta karya sederhana, mewarnai, melipat, dll.

Jadi, dapat diketahui hasil dari pelaksanaan program pendidikan inklusif ruang sumber di SDN 4 Karangpatihan memberikan pengaruh yang positif dalam peningkatan kemampuan dan potensi 
peserta didik khususnya tunagrahita dari aspek kognitif, sikap, dan keterampilan, sehingga anak dapat menjalani hidupnya secara mandiri tanpa membebani orang lain.

Demikian juga hal yang sama terjadi di SDLB C Pertiwi Ponorogo. Adanya pembelajaran yang intensif serta adanya publikasi dan pelatihan bina diri dan ketrampilan menjadikan anak mampu dan memiliki motivasi tersendiri dalam belajar. Kendala yang sama ditunjukkan oleh siswa di Lembaga tersebut yakni semakin lemahnya kondisi fisik dan IQ menjadi perhatian sendiri, sehingga adanya bina diri dan ketrampilan sangat perlu dilaksanakan.

\section{E. Kesimpulan}

Berdasarkan hasil penelitian tentang Desain Pendidikan Khusus Peserta Didik Tunagrahita di SDN 4 Karangpatihan Balong Ponorogo dan SDLB C Pertiwi Ponorogo, dapat disimpulkan bahwa:

1. Bentuk program pendidikan inklusif di SDN 4 Karangpatihan adalah program pembelajaran intensif di ruang sumber bagi peserta didik tunagrahita yang dilakukan secara kontinyu dengan memperhatikan kebutuhan individual anak untuk meningkatkan kemampuan dan potensi mereka. Sedangkan di SDLB C Pertiwi Ponorogo bentuk pelayanan pendidikan nya menggunakan pembelajaran intensif 4 hari dan dua 2 dengan kegiatan latih bina diri.

2. Strategi dalam menerapkan program pendidikan inklusif di SDN 4 Karangpatihan yaitu (a) memberikan pembelajaran yang berorientasi pada kebutuhan peserta didik dan kondisi sekolah, (b) pembelajaran ABK secara terpadu (semua ABK belajar dalam satu kelas dengan suasana pembelajaran yang sama) dan (c) peningkatan kualitas guru. Sedangkan di SDLB Pertiwi Ponorogo dengan mengadakan Gebyar ABK dan strategi pembelajaran person by person.

3. Hasil pelaksanaan program pendidikan inklusif di SDN 4 Karangpatihan yaitu dapat memberikan perubahan positif dan bervariatif sesuai potensi dan kebutuhan anak dengan menekankan pada perkembangan kognitif, sedangkan peningkatan aspek sikap dan pikomotorik belum bisa maksimal. Sedangkan hasil pelaksanaan program di SDLB C pertiwi Ponorogo yaitu mereka mampu membaca walaupun belum memahami arti bacaannya, sedangkan dari aspek latih bina diri mampu menghasilkan kemampuan bina diri dan ketrampilan yang baik.

\section{REFERENSI}

Creswell, John W. Qualitative Inquiry and Research Design: Choosing among Five Approaches. London: Sage Publications, 1998.

Desmita. Psikologi Perkembangan Peserta Didik. Bandung: Remaja Rosdakarya, 2016.

Masnu'ah. Wawancara, Kamis Mei Pukul 08.30 WIB 2018.

-_. Wawancara, Kamis Mei Pukul 08.30 WIB 2018.

Setiawan, Atang. Bimbingan Anak Berkebutuhan Khusus. Bandung: UPI Press, 2006.

Walidah, Zahrotul. Wawancara, Kamis Mei Pukul 08.30 WIB 2018. 